\title{
Use of a mixture of barley-based fermented grains and wheat gluten as an alternative protein source in practical diets for Litopenaeus vannamei (Boone)
}

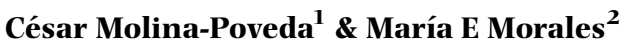 \\ ${ }^{1}$ Foundation CENAIM-ESPOL, Campus Politécnico Prosperina, Guayaquil, Ecuador \\ ${ }^{2}$ Facultad de Ciencias Quimicas, Universidad de Guayaquil, Ciudadela Universitaria ‘Salvador Allende’, Guayaquil, Ecuador
}

Correspondence: C Molina-Poveda, Foundation CENAIM-ESPOL, Campus Politécnico Prosperina, Vía perimetral Km 30.5. Casilla 09-014519, Guayaquil, Ecuador. E-mail: cemolina@cenaim.espol.edu.ec

\begin{abstract}
A combination of barley-based fermented grains (BFG) and wheat gluten (WG) meal (1:1 on a crude protein basis) was evaluated as an alternative protein-rich ingredient (BFG-WG) in diets for juvenile Litopenaeus vannamei. Four isocaloric diets were formulated to contain $44 \%$ protein in which protein from BFG-WG replaced 0\% (A), 33\% (B), 66\% (C) and $100 \%$ (D) of the protein from marine animal protein (MAP: $69 \%$ shrimp head meal, $21 \%$ fish meal and $10 \%$ squid meal) in the diets. These diets were delivered twice a day for 6 weeks to shrimp (initial weight \pm standard error, $2.14 \pm 0.02 \mathrm{~g}$ ). Shrimp fed diets A (control) and B showed similar weight gain at the end of the experiment. There were no significant differences among the survival rates of different dietary treatments $(>96 \%)$. The amount of uneaten food was positively and significantly $\left(r^{2}=0.57, P<\right.$ 0.001 ) related to the level of inclusion of BFG-WG in the diets, suggesting that diet palatability was a major factor influencing shrimp growth. Diet D had the highest apparent digestibility for protein and dry matter. The inclusion of BFG-WG had a positive effect $\left(r^{2}=0.75, P<0.05\right)$ on carbohydrate digestibility. A significant stimulation of amylase activity and soluble protein and glycogen concentrations in the hepatopancreas also was related to the amount of BFG-WG in the diet. Feed conversion ratio and protein efficiency ratio were not significantly different among diets containing substitution levels of $0 \%$, $33 \%$ and $66 \%$ of MAP, which could suggest that if the balance of amino acids and the palatability in the diet can be improved, replacement level of the MAP may be increased to $66 \%$ without reducing growth.
\end{abstract}

Keywords: amylase, barley-based fermented grains, growth, digestibility, Litopenaeus vannamei, marine animal protein, wheat gluten meal

\section{Introduction}

The increasing demand of seafood for human consumption has resulted in a constant growth of global aquaculture production (FAO 1999). A fundamental component of diets used in the culture of aquatic commercial species is protein of marine animal origin (MAP). However, its cost and increasing demand are driving the search for alternative sources of protein for use in diets for fish and shrimp.

The recommended protein content of shrimp feeds varies from $30 \%$ to $55 \%$ (Akiyama 1991). In most cases, diets contain varying proportions of fish meal, shrimp head meal and squid meal (Akiyama 1991). These ingredients are of high nutritional value and palatability, but are relatively expensive. Feed costs represent the largest component of the cost of shrimp production. In semi-intensive culture, feed can account for $28 \%$ of the total costs (Treece 2000). As the marine protein source is one of the most expensive components of the feed, lowering its inclusion to a level that does not adversely affect the growth rate of the species in culture may result in lower production costs.

Numerous investigations have been made to evaluate protein-rich ingredients in shrimp feeds: soybean (Akiyama 1991), canola (Cruz-Suarez, Ricque-Marie, Tapia-Salazar, McCallum \& Hickling 2001), cottonseed (Lim 1996), peanut (Lim 1997), blood (Dominy \& Ako 1988), fisheries by-product (Sudaryono, Hoxey, Kailis \& Evans 1995) and poultry by-product meal 
(Davis \& Arnold 2000). At the experimental level, leaf meals of camote and papaya (Peñaflorida 1995) and meals of feed pea, cowpea and rice bean (Eusebio 1991; Cruz-Suarez et al. 2001) have also been evaluated.

Due to its nutritional value, relatively low cost and the consistent availability, soybean meal is frequently included in diets for fish and shrimp throughout the world. Davis and Arnold (2000), working with Litopenaeus vannamei, did not observe differences in survival, feed conversion and protein efficiency when they replaced up to $80 \%$ fish meal protein with co-extruded soybean meal and poultry by-product meal in isonitrogenous diets.

Stillage and distillers grains are obtained as byproducts of the distillation industry in which starch grains are fermented to produce alcohol (Webster, Tidwell, Goodgame, Yancey \& Mackey 1992). Traditionally, barley grain is an important cereal used in the brewing industry in Ecuador, and is used either on its own or in combination with rice to reduce the production costs of beer. Due to differences in the content of the seed coating of the barley, the fermented by-product is variable in its composition. The limited amount of data that has been published about the nutritional value of distilled grains is based on $100 \%$ barley. Wu (1986) reported that barley-based distillers grains (BFG) had $32.6 \%$ crude protein, $6 \%$ fat, $4.4 \%$ ash and $16.6 \%$ crude fibre. The effect of BFG on shrimp was initially investigated through the direct addition of BFG to culture ponds, where it was shown to contribute to the nutrition of Macrobrachium rosenbergii (Kohler \& Krueger 1985). Tidwell, Webster, Yancey and D’Abramo (1993), working with $M$. rosenbergii, found that the replacement of $50 \%$ or $100 \%$ fish meal with a combination of soybean meal and distillers dried grains with solubles did not result in a reduction in weight gain, survival and yield when compared with the diet containing only fish meal. In order to consider the use of alternative protein sources, either as partial or total replacement of marine protein, the quality of these sources, including the proteins of marine origin, needs to be evaluated in terms of chemical composition, biological value and digestibility.

There appears to be no information in the scientific literature relating to the use of the BFG as a substitute for a mixture of fish, shrimp and squid meals. Hence, the objective of the present study was to evaluate BFG as an alternative protein source in diets of juvenile $L$. vannamei. However, since BFG has an intermediate level of protein (29.3\% dry basis), wheat gluten meal
(WG) was used to create a mixed ingredient (BFGWG) with a protein content of $45.9 \%$.

\section{Materials and methods}

\section{Experimental design}

The feeding trial was conducted in the experimental facilities of the National Aquaculture and Marine Research Centre (CENAIM), San Pedro de Manglaralto (Guayas Province, Ecuador). Juvenile L. vannamei having a mean (standard error, SE) body weight of $2.14(0.02) \mathrm{g}$, were randomly distributed with five shrimp in each of $20 \times 50$-L polyethylene aquaria $(60 \times 30 \times 36 \mathrm{~cm} L \times W \times H)$ supplied with aerated seawater (flow $0.35 \mathrm{~L} \mathrm{~min}^{-1}$, dissolved oxygen $6.3-8.3 \mathrm{mgL}^{-1}$; pH 7.6-8.8; salinity 32-34\%; temperature $26.0-27.4^{\circ} \mathrm{C}$ ). Aquaria were covered with 2-mm mesh netting to prevent shrimps from escaping. Photoperiod was controlled at 12D:12L.

Each of the four test diets was randomly assigned to five aquaria. Shrimp were fed at $10 \%$ of the body weight twice daily (09:00 and 16:00 hours) for 6 weeks in order to establish any differences in growth, biomass, survival and feed conversion ratio. During the first 2 days, dead shrimp were replaced with shrimp having similar weight. Uneaten feed, moults and faeces were siphoned out every morning before the first feeding. All shrimp were individually weighed every 15 days to evaluate growth and adjust feeding rations.

During the fourth week, over 3 consecutive days, the uneaten feed was collected $2 \mathrm{~h}$ after feeding by siphoning, dried at $60{ }^{\circ} \mathrm{C}$ for $24 \mathrm{~h}$ and weighed again. The amount of non-consumed feed by shrimp was expressed as a percentage of the biomass of shrimp in the aquaria and used as an indicator of diet palatability.

One week before the end of the grow th experiment, shrimp were fed on their assigned diets that had been supplemented with $1 \%$ chromic oxide in order to acclimate shrimps to the new feed. After that period, faeces were collected twice a day, $2 \mathrm{~h}$ after feeding, and pooled for each aquaria. Faecal material collected during 10 days were frozen and freeze-dried before analyses.

The apparent digestibility (AD) of the test diets were calculated using the formula:

$$
\mathrm{AD}=1-\frac{\left(\% \text { nutrient } / \% \mathrm{Cr}_{2} \mathrm{O}_{3}\right) \text { faeces }}{\left(\% \text { nutrient } / \% \mathrm{Cr}_{2} \mathrm{O}_{3}\right) \text { diets }} \times 100 \text {. }
$$

At the end of digestibility trial, 10 shrimp in early premolt stage (Do) were randomly chosen between 
09:00 and 11:00 hours (after 15-h fasting) from the experimental aquaria and sacrificed (Le Moullac, Klein, Sellos \& Van Wormhoudt 1997). Immediately, their hepatopancreas were excised to measure amylase activity, soluble protein and glycogen content, and also to determine hepatosomatic index (HSI).

\section{Diet formulation}

Samples of dry BFG were supplied by The Cervecería Nacional del Ecuador brewery plant at Guayaquil, Guayas Province, Ecuador. The BFG consisted of the post-fermentation by-product of a mixture of $80 \%$ barley, $10 \%$ rice and $10 \%$ lupulo/corn mixture. Four isocaloric diets were formulated containing $44 \%$ of protein, in which the mixture of marine animal protein composed of $69 \%$ shrimp head meal, $21 \%$ fish meal and $10 \%$ squid meal was replaced with $0 \%$, $33 \%, 66 \%$ and $100 \%$ of a mixture of BFG and WG (1:1 on a crude protein basis) (Table 1). Because of the low protein content of BFG (29.3\% dry basis), WG was included in the mixture to increase the protein content of the mixture. It was used because of its high digestibility (Akiyama, Coelho, Lawrence \& Robinson 1989).

Table 1 Formulation and chemical composition of the experimental diets

\begin{tabular}{|c|c|c|c|c|}
\hline Ingredients (\%) & A & B & C & D \\
\hline Shrimp head meal ${ }^{*} \dagger$ & 33.40 & 22.40 & 11.40 & 00.00 \\
\hline Fish meal † & 10.00 & 6.70 & 3.40 & 00.00 \\
\hline Squid meal§ & 5.00 & 3.35 & 1.70 & 00.00 \\
\hline$-\mathrm{WG} \|^{* *}-\mathrm{BFG} \dagger \dagger$ & 2.95 & 23.56 & 44.18 & 65.31 \\
\hline Soybean meal $\ddagger \ddagger \dagger$ & 20.00 & 20.00 & 20.00 & 20.00 \\
\hline Cod liver oil§§ & 4.98 & 5.24 & 5.26 & 2.43 \\
\hline Soybean lecithin $\dagger$ & 1.00 & 1.00 & 1.00 & 1.00 \\
\hline Cholesterol** $^{* *}$ & 0.50 & 0.50 & 0.50 & 0.50 \\
\hline Vitamin mix & 4.50 & 4.50 & 4.50 & 4.50 \\
\hline Mineral mix \| \| & 2.00 & 2.00 & 2.00 & 2.00 \\
\hline Binder Pegabind ${ }^{\circledR}$ & 1.00 & 1.00 & 1.00 & 1.00 \\
\hline Antioxidant Ethoxyquin ${ }^{\mathbb{R}}$ & 0.02 & 0.02 & 0.02 & 0.02 \\
\hline Chromic Oxide $\left(\mathrm{Cr}_{2} \mathrm{O}_{3}\right)^{* *}$ & 1.00 & 1.00 & 1.00 & 1.00 \\
\hline Corn starch*** & 13.66 & 6.71 & 0.00 & 0.00 \\
\hline Diatomaceous earth $\left(\mathrm{SiO}_{2}\right)^{* *}$ & 0.00 & 2.08 & 4.15 & 2.25 \\
\hline \multicolumn{5}{|l|}{ Proximate composition } \\
\hline Dry matter (\% DM) & 89.7 & 88.6 & 89.5 & 86.4 \\
\hline Crude protein $(\mathrm{N} \times 6.25 ; \% \mathrm{DM})$ & 43.7 & 43.8 & 44.2 & 44.9 \\
\hline Lipids (\% DM) & 12.4 & 13.0 & 12.2 & 8.0 \\
\hline Total fibre (\% DM) & 6.9 & 5.2 & 3.3 & 1.0 \\
\hline Ash (\% DM) & 15.5 & 15.1 & 14.3 & 15.0 \\
\hline Calculated gross energy ( $\left.\mathrm{kJ} \mathrm{g}^{-1} \mathrm{DM}\right)$ & 15.6 & 16.1 & 16.4 & 15.8 \\
\hline
\end{tabular}

*Commercial shrimp head meal (44.3\% crude protein (c.p.); $5.8 \%$ lipid).

$\dagger$ Purchased from Alimentsa S.A. (Guayaquil, Ecuador).

$\ddagger$ Produced by steam dry method (60.7\% c.p.; $10.5 \%$ lipid); Polar (Salango, Ecuador).

§Processed in the laboratory by liophilized from commercial frozen baby squid Loligo sp. (61.7\% c.p.; 10.1\% lipid).

-Wheat gluten (WG)/barley-based fermented grains (BFG) ratio of 0.4 in mixture except for diet A $(0 \% \mathrm{BFG})$.

\|WG contained $80.5 \%$ c.p.; $5.5 \%$ lipid.

** Purchased from Sigma Chemical.

$\dagger †$ BFG contained $31.9 \%$ c.p.; $11.5 \%$ lipid; $4.5 \%$ fibre; $4.0 \%$ ash; $50.2 \%$ carbohydrate. The Cervecería Nacional del Ecuador, Guayaquil, Ecuador.

††̣Defatted soybean meal (54.8\% c.p.; $4.8 \%$ lipid).

$\S \S$ Provided by Aristes (Wilton, USA).

ๆ $\mathrm{mg} 100 \mathrm{~g}^{-1}$ diet: p-aminobenzoic acid, 10; thiamin-HCl, 12; riboflavin, 20; pyridoxine-HCl, 12; choline chloride, 250; nicotinic acid, 75; calcium pantothenate, 50; inositol, 200; biotin, 0.5; folic acid, 1.5; ascorbic acid, 10; menadione, 4; $\alpha$-tocopherol acetate, 40; cyanocolabamine, 0.03; cholecalciferol, 0.03; $\beta$-carotene, $1.15 \times 10^{-3}$.

\|||mg $100 \mathrm{~g}^{-1}$ diet: calcium phosphate monobasic, 272; calcium lactate, 640.2; ferric citrate, 60; magnesium sulphate heptahydrate, 274; potasium phosphate, 480; sodium phosphate monobasic, 174; sodium chloride, 86; aluminium chloride, 0.4; potasium iodide, 0.3; cuprous chloride, 0.2; manganous sulphate monohydrate, 1.6; cobalt chloride hexahydrate, 2.1; zinc sulphate heptahydrate, 7.1; sodium selenite, 2.

***Purchased from Sumesa S.A. (Guayaquil, Ecuador). 
The energy content of the diets was adjusted by varying corn starch and cod liver oil using physiological values for calculating the energy level (Lim 1997). Chromic oxide was included in the diets at a level of $1 \%$ as inert marker to evaluate dry matter (ADMD), protein (APD) and carbohydrate (ACD) digestibility.

Once all of the dry ingredients were mixed by hand, soy lecithin and oil were added. Finally, water was added gradually $\left(400-500 \mathrm{~mL} \mathrm{~kg}^{-1}\right)$ until the resulting dough could be easily extruded. The moist mixture was extruded in a 2-mm diameter die of a meat mincer. The 'spaghetti-like' strands $5-10-\mathrm{cm}$ long were dried in a fan-ventilated oven at $60^{\circ} \mathrm{C}$ for $2 \mathrm{~h}$. After drying, strands were broken up into pellets of about 1-cm length, packed in sealed plastic bags and then stored at $-10{ }^{\circ} \mathrm{C}$ until use.

\section{Analytical methods}

Feed ingredients and diets were milled to fine powder $(300 \mu \mathrm{m})$ and their proximate compositions were analysed according to standard laboratory procedures (AOAC 1990). Dry matter was calculated from weight loss after drying in an oven at $135^{\circ} \mathrm{C}$ for $2 \mathrm{~h}$; ash was determined after ignition of the samples at $550{ }^{\circ} \mathrm{C}$ for $4 \mathrm{~h}$ in a muffle furnace; crude protein $(\% \mathrm{~N} \times 6.25)$ was measured using Kjeldahl method after acid digestion; crude fibre content was determined using Weende method on Fibermatic system (Mitamura Riken ${ }^{\circledR}$, Tokyo, Japan). Total lipid was determined by a modification of the Folch method (Folch, Lees \& Sloane-Stanley 1957).

For determination of APD, ACD and ADMD, protein content of faeces and diets was measured according to the procedure described by Foster and Gabbot (1971). Carbohydrate and chromic oxide were analysed in five replicates of the diets and faeces according to Nelson (1944) and McGinnis and Kasting (1964) respectively.

The hepatopancreas were weighed and homogenized in 1.5-mL deionized water. Homogenates were centrifuged for $5 \mathrm{~min}$ at $28600 \mathrm{~g}$ and $4{ }^{\circ} \mathrm{C}$ and the supernatants free of the lipid layer were stored in 1$\mathrm{mL}$ Eppendorf tubes at $-20{ }^{\circ} \mathrm{C}$ until analysis. Amylase activity was determined using the method of Rick and Stegbauer (1984). Enzyme activity was expressed as units per milligram soluble protein $\left(\mathrm{Umg}^{-1}\right)$. Total soluble protein and glycogen were measured based on the methods described by Lowry, Rosebrough, Farr and Randall (1951) and Dubois, Gilles, Hamilton, Rebers and Smith (1956) using bovine serum albumin and glucose as standards respectively. All analyses were carried out in triplicate, except for digestibility analyses.

All data are presented as the mean values \pm SE. The Anderson-Darling test was used to check for normality. Bartlett's test for homogeneity of variance was employed with $\alpha=0.05$ (Zar 1999). Analysis of variance and, when pertinent, a posteriori Fisher's pairwise comparisons were used to identify differences at the 0.05 probability level. Correlations were determined using linear regression analysis. Percent composition data was transformed to arcsine prior to analysis.

\section{Results}

The amount of uneaten food was positively $\left(r^{2}=0.57\right.$, $P<0.001)$ related to the level of substitution of MAP in the diets (Fig. 1). Shrimp fed diets C and D showed a significantly $(P<0.05)$ lower consumption than those fed $\operatorname{diet} \mathrm{A}$, whereas there was no significant difference between diets $A$ and $B$ or between diets $C$ and $D$.

At the end of the 45-day growth trial, there were no significant differences $(P>0.05)$ among survival rates of the different dietary treatments (>96\%). The incremental increase in BFG-WG in diets produced a significant decrease $(P<0.05)$ in the final biomass (Table 2). Diets $C$ and D yielded the lowest biomass gain in comparison with diets $\mathrm{A}$ and $\mathrm{B}$. No significant difference $(P>0.05)$ was found in growth performance between shrimps fed diet $\mathrm{B}$ and the control diet (Table 2). Shrimp fed diet D containing no MAP showed the worst growth.

In this study, the APD and ADMD varied from $82.5 \%$ to $90.0 \%$ and from $69.1 \%$ to $78.8 \%$ respective-

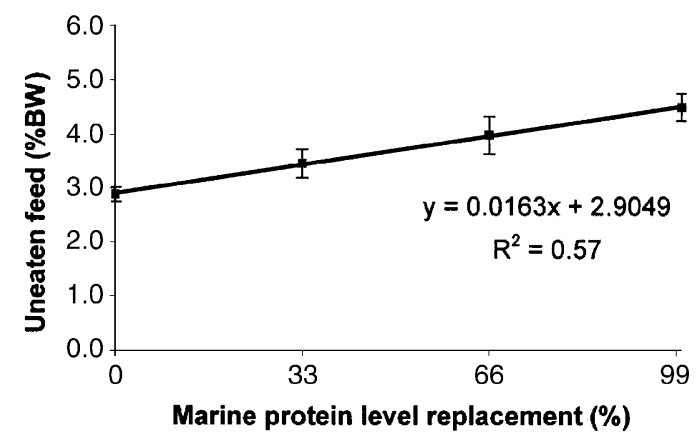

Figure 1 Relationship between the amount of non-consumed feed and the level of marine protein substitution in diets evaluated in juvenile Litopenaeus vannamei feeding experiment. Means \pm SE. 
Table 2 Physiological response observed in Litopenaeus vannamei fed with diets evaluated in this study for 6 weeks*

\begin{tabular}{lcccc}
\hline \multicolumn{5}{l}{ Marine protein level replacement (\%) } \\
\cline { 2 - 5 } Diets & $\mathbf{0}$ & $\mathbf{3 3}$ & $\mathbf{6 6}$ & $\mathbf{1 0 0}$ \\
\hline Weight gain (\%) $\dagger$ & $256.8 \pm 20.0 \mathrm{a}$ & $244.1 \pm 23.5 \mathrm{a}$ & $192.7 \pm 17.7 \mathrm{~b}$ & $116.9 \pm 3.2 \mathrm{~b}$ \\
Survival (\%) & $96 \mathrm{a}$ & $96 \mathrm{a}$ & $100 \mathrm{a}$ & $96 \mathrm{a}$ \\
Biomass (g) & $182.9 \mathrm{a}$ & $174.9 \mathrm{a}$ & $154.7 \mathrm{~b}$ & $113.4 \mathrm{~b}$ \\
FCR $\ddagger$ & $2.3 \pm 0.3 \mathrm{a}$ & $2.5 \pm 0.2 \mathrm{a}$ & $3.0 \pm 0.3 \mathrm{a}$ & $4.6 \pm 0.4 \mathrm{~b}$ \\
PER & $1.0 \pm 0.1 \mathrm{a}$ & $0.9 \pm 0.1 \mathrm{a}$ & $0.8 \pm 0.1 \mathrm{a}$ & $0.5 \pm 0.1 \mathrm{~b}$ \\
Protein & $315 \pm 63.5 \mathrm{a}$ & $333 \pm 43.4 \mathrm{a}$ & $453 \pm 46.9 \mathrm{~b}$ & $548 \pm 61.7 \mathrm{c}$ \\
Glycogen & $2.7 \pm 0.4 \mathrm{a}$ & $2.1 \pm 0.5 \mathrm{a}$ & $4.7 \pm 0.7 \mathrm{~b}$ & $5.2 \pm 1.1 \mathrm{~b}$ \\
HSI (\%) $\|$ & $4.1 \pm 0.2 \mathrm{a}$ & $4.2 \pm 0.3 \mathrm{a}$ & $4.5 \pm 0.4 \mathrm{a}$ & $4.1 \pm 0.3 \mathrm{a}$ \\
Amylase $\left(\mathrm{Umg}^{-1}\right)$ & $10 \pm 0.9 \mathrm{a}$ & $65 \pm 8.5 \mathrm{~b}$ & $77 \pm 9.8 \mathrm{bc}$ & $97 \pm 12.5 \mathrm{c}$ \\
\hline
\end{tabular}

${ }^{*}$ Means \pm SE in the same row not sharing a common letter were significantly different $(P<0.05)$.

$\dagger$ Weight gain $(\%)=($ final weight - initial weight $) /$ initial weight $\times 100$.

$\ddagger$ Feed conversion ratio $(\mathrm{FCR})=$ dry feed fed $(\mathrm{g}) /$ wet weight gain $(\mathrm{g})$.

§Protein efficiency ratio $(\mathrm{PER})=$ wet weight gain $(\mathrm{g}) /$ protein consumed $(\mathrm{g})$.

TExpressed as $\mathrm{mg} \mathrm{g}^{-1}$ hepatopancreas.

$\|$ Hepatosomatic index $(\mathrm{HSI})=[$ hepatopancreas wet weight $(\mathrm{g}) /$ shrimp wet weight $(\mathrm{g})] \times 100$.

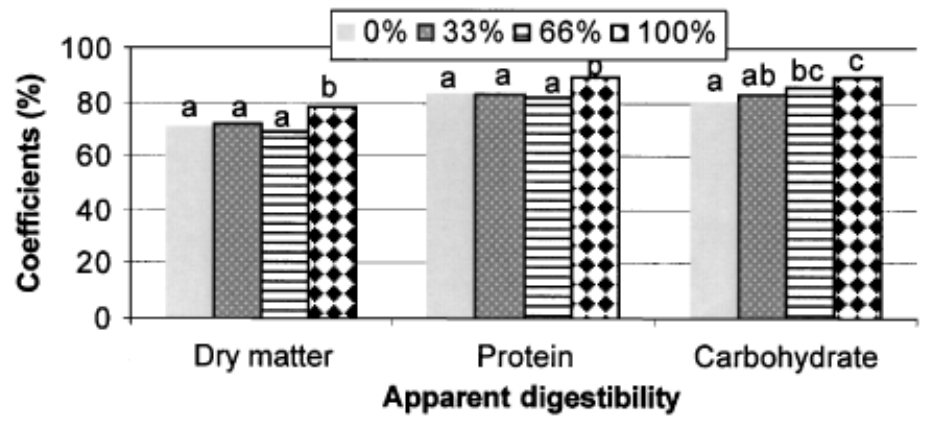

ly (Fig. 2). The diet with total substitution of MAP had a significantly $(P<0.05)$ higher digestibility when compared with the other diets. The digestibility of diets $\mathrm{B}$ and $\mathrm{C}$ were not significantly different from the control diet. The inclusion of BFG-WG had a significantly positive effect on ACD, since this was directly correlated with the substitution level of MAP in the rank of $0-100 \%$ (coefficient of Pearson correlation, 0.75, $P<0.001$ ). Apparent carbohydrate digestibility in control diet A was significantly lower as compared with diets $C$ and D containing $66 \%$ and $100 \%$ of replacement (Fig. 2).

A significant $(P<0.05)$ stimulation of amylase activity and soluble protein and glycogen concentrations in the hepatopancreas was related to replacement level of MAP (Table 2). An increase from 33\% to $100 \%$ in the substitution level of dietary MAP increased substantially amylase specific activity (seven to nine times) in juvenile L. vannamei, compared with values reached in shrimps fed with control diet. Shrimp fed diet D showed the highest value of protein concentration (548 $\mathrm{mg} \mathrm{g}^{-1}$ hepatopancreas), while no differences were observed between $A$ and $B$ diets. The glycogen content in the hepatopancreas of dietary treatments $\mathrm{A}$ and $\mathrm{B}$ was lower than diets $\mathrm{C}$ and $\mathrm{D}$. This difference was at least $2 \mu \mathrm{g} \mathrm{g}^{-1}$ hepatopancreas. Similarly, an increase in the HSI in relation to decrease of the MAP was observed, although significant differences were not found $(P>0.05)$ among evaluated diets.

Feed conversion ratio and protein efficiency ratio of diets containing between $0 \%$ and $66 \%$ of replacement were not significantly different $(P>0.05)$ (Table 2$)$.

\section{Discussion}

The present study shows that a replacement more than $33 \%$ of MAP in shrimp feed adversely affect feed intake. This response seems to be related to a decrease in palatability of the feed as MAP is replaced with BFG-WG. Dietary inclusion levels of up to a maximum of $20 \%$ of WG has been suggested for penaeid 
shrimp, its use being limited by cost rather than palatability (Tacon \& Akiyama 1997). In the present study, dietary WG content (3-17\%) was below the maximum recommended level. On the contrary, it has been reported that malt flour, obtained from the by-product of beer distillation, was not palatable for trout Oncorhynchus mykiss (Yamamoto, Marcouli, Unuma \& Akiyama 1994). Yamamoto, Unuma, Akiyama and Kishi (1996) also noted that high inclusion levels of malt protein flour in the diet decreased the rate of feed consumption in red sea bream Pagrus major. The effect of BFG on diet palatability by L. vannamei has not previously been reported in the literature, but certain ingredients as beer yeast present in brewery by-products have been mentioned as having a repellent effect to fish (Métailler \& Guilllaume 2001). However, Kohler and Krueger (1985) indicated that BFG was a food source for freshwater prawn $M$. rosenbergii in pond culture and served as substrate for other organisms. However, this does not imply that BFG was the primary source of nutrients.

The body weight gain in the shrimp followed the trend of feed intake and decreased gradually with a decrease in MAP concentration of feed. The reductions in growth observed in experiments where fish meal or other MAP were replaced by alternative protein sources have been attributed to anti-nutritive factors and inadequate amino acid and mineral balance of tested sources (Lim \& Dominy 1991). Barleybased fermented grains is constituted mainly of germinated barley which is known to be deficient in the essential amino acid lysine (Akiyama, Unuma, Yamamoto, Marcouli \& Kishi 1995), like malt. Distillers grains with solubles have been shown to be a good diet ingredient for channel catfish at levels up to 30$40 \%$ of the diet without lysine supplementation (Webster, Tidwell \& Yancey 1991; Webster, Tidwell, Goodgame \& Johnsen 1993). Nevertheless, Webster and colleagues (1992) noted that channel catfish receiving a diet containing $0 \%$ fish meal and 35\% distillers grains with solubles, but supplemented with lysine, showed improved weight gain. The inconsistency among these findings could be attributed to the trials being carried out in ponds where natural biota may have supplemented any amino acids imbalance in diets tested, whereas Webster and colleagues (1992) conducted their feeding experiment in aquaria. Since lysine is also the first limiting amino acid in WG (Akiyama et al. 1989), it is reasonable to assume that the replacement of MAP with BFG-WG under isonitrogenous and isocaloric conditions had also a negative effect on weight gain due to deficiency of lysine or other amino acids in the diet. This fact can be inferred comparing results between diets $\mathrm{B}$ and $\mathrm{C}$ where there was no difference in feed intake but there was a difference in growth. Hence, the optimal supplementation of lysine and eventually other essential amino acids must be considered in future studies with shrimp.

Numerous investigations have demonstrated that utilization of dietary carbohydrates by shrimp varies with starch complexity and processing of the carbohydrate (Shiau \& Peng 1992; Glass \& Stark 1995). The brewing beer process involves two main steps, that is, mashing and yeast fermentation. During mashing starch is converted into dextrin, maltose and glucose, which are considered as soluble carbohydrates. In the present investigation, the ACD seemed to be related to a greater availability of soluble carbohydrates present in BFG (50\%) as the level of this ingredient increased in the diet. Romero (1999) found an increase in ACD with the progressive inclusion of gelatinized cassava starch in isonitrogenous diets for L. vannamei. Apparently, the use of processed starch for gelatinization improves not only carbohydrate digestibility but also dry matter and energy digestibilities for marine shrimps (Davis \& Arnold 1995) and some fish (Bergot \& Bresque 1983).

The dietary fibre level decreased as MAP was replaced. This was attributed to a reduction in the amount of dietary shrimp head meal, which is rich in chitin (Akiyama et al. 1989). Akiyama and colleagues (1989) found that the high chitin or fibre contents $(88 \%)$ in diets decreases the APD in $L$. vannamei. In this study, that finding is unlikely to apply as the differences in fibre content between control diet $A$ and the other diets $(6.9 \%$ vs. $1.0-5.2 \%)$ were not large. Our result is consistent with the results of Sudaryono, Tsvetnenko and Evans (1996) who concluded that changes in fibre content of Penaeus monodon diets did not appear to cause a change in APD. The highest APD obtained for diet D may be attributable to the greater inclusion level of WG. Wheat gluten is one of the most digestible protein sources (98\%) among feedstuffs evaluated for L. vannamei (Akiyama et al. 1989). A protein:carbohydrate interaction could also explain observed increased digestibility of diet D, as reported by Romero (1999) for L. vannamei. Under these circumstances, clear conclusions for the observed increase in protein digestion cannot be made.

The higher amylase activity in shrimps fed diets containing BFG could also be a consequence of soluble carbohydrate content $(50 \%)$ present in BFG unlike WG (Sigma Chemical, St Louis, MO, USA), 
which may have stimulated $\alpha$-amylase secretion as described previously by Romero (1999). Glass and Stark (1995) demonstrated by means of digestibility in vitro that micronized and cooked grains are more susceptible to amylolytic attack than non-treated crude starch grains. Rosas, Cuzon, Gaxiola, Arena, Lemaire, Soyez and Van Wormhoudt (2000) also observed that increasing carbohydrate level from $1 \%$ to $33 \%$ in diet, resulted in a stimulation of $\alpha$-amylase and $\alpha$-glucosidase activities in the hepatopancreas of Litopenaeus stylirostris.

Evidence for an enhanced glycogen content in shrimp hepatopancreas with BFG-WG treatments suggested improved absorption and assimilation of glucose from the carbohydrate component in these diets. This was more evident at diets C and D as compared with the hepatopancreatic glycogen measured in the control group. Shrimp fasted for $15 \mathrm{~h}$ prior to the hepatopancreas extraction showed a noticeable glycogen deposition close to $6 \mathrm{mg} \mathrm{g}^{-1}$ hepatopancreas in those fed diets $C$ and $D$. This result is comparable with the level of $4.3-6.9 \mathrm{mg} \mathrm{g}^{-1}$ found in L. stylirostris (Rosas et al. 2000). These authors reported a maximum glycogen storage capacity with $21 \%$ dietary carbohydrates for L. stylirrostris and 23\% carbohydrates in diet for $L$. setiferus and L. vannamei. A saturation degree may explain the limited capacity of penaeids to store and digest dietary carbohydrates. Changes in the shrimps hepatopancreas weight have been attributed to variations in glycogen deposition (Gibson \& Barker 1979). No significant effect was observed in the present study for any dietary treatments on the HSI, probably due to the high data variability observed.

\section{Conclusions and recommendations}

1. Substitution of the MAP up to $33 \%$ did not alter growth performance or feed utilization compared with the control diet.

2. These results suggest that if amino acid balance and palatability can be improved, the dietary level of MAP could be replaced up to $66 \%$ without lowering performance of shrimp grown in the absence of natural biota.

3. The Cervecería Nacional del Ecuador produces daily around $50 \mathrm{~m}^{3}$ containing $750 \mathrm{~kg}$ of protein. This amount is sufficient to produce approximately 5000 tonnes of feed containing $44 \%$ protein with $16 \%$ of BFG for 330 days.

4. The experiment should be repeated under pond conditions.

\section{Acknowledgments}

The authors wish to thank Dr Stanislaus Sonnenholzner for English corrections and Dr Patrick Sorgeloos and Dr David Smith for constructive comments on the paper. We would also like to thank Yela Paredes for her kind support and Ma. Elena Solórzano for her technical assistance. Special thanks to the Cervecería Nacional del Ecuador for providing the fermented grain.

\section{References}

Akiyama D.M. (1991) Soybean meal utilization by marine shrimp. In: Proceedings of the aquaculture feed processing and nutrition workshop. (ed. by D.M. Akiyama \& R.K.H. Tan), pp 207-225. American Soybean Association, Singapore, September 19-25.

Akiyama D.M., Coelho S.R., Lawrence A.L. \& Robinson E.H. (1989) Apparent digestibility of feedstuffs by the marine shrimp Penaeus vannamei BOONE. Nippon Suisan Gakkaishi 55, 91-98.

Akiyama T., Unuma T., Yamamoto T., Marcouli P. \& Kishi S. (1995) Combinational use of malt protein flour and soybean meal as alternative protein sources of fish meal in fingerling rainbow trout diets. Fisheries Science 61, 828-832.

AOAC (1990) Official Methods of Analysis, 15th edn. Association of Official Analytical Chemists, Arlington, VA, USA, 1298pp.

Bergot F. \& Bresque J. (1983) Digestibility of starch by rainbow trout: effects of physical state of starch and of the intake level. Aquaculture 34, 203-212.

Cruz-Suarez L.E., Ricque-Marie D., Tapia-Salazar M., McCallum I.M. \& Hickling D. (2001) Assessment of differently processed feed pea (Pisum sativum) meals and canola meal (Brassica sp.) in diets for blue shrimp (Litopenaeus stylirostris). Aquaculture 196, 87-104.

Davis D.A. \& Arnold C.R. (1995) Effects of two extrusion processing conditions on the digestibility of four cereal grains for Penaeus vannamei. Aquaculture 133, 287-294.

Davis A.D. \& Arnold C.R. (2000) Replacement of fish meal in practical diets for the Pacific white shrimp, Litopenaeus vannamei. Aquaculture 185, 291-298.

Dominy W.G. \& Ako H. (1988) The utilization of blood meal as a protein ingredient in the diet of the marine shrimp Penaeus vannamei. Aquaculture 70, 280-299.

Dubois M., Gilles K.A., Hamilton J.K., Rebers P.A. \& Smith F. (1956) Colorimetric method for determination of sugar and related substances. Analytical Chemistry 28, 350-356.

Eusebio P.S. (1991) Effect of dehulling on the nutritive value of some leguminous seeds as protein sources for juvenile tiger prawn, Penaeus monodon. Aquaculture 99, 297-308.

FAO (1999) Aquaculture production statistics 1988-1997. Fisheries Circular, No 815, Revision 11: Rome, Italy, 203pp.

Folch J., Lees M. \& Sloane-Stanley G.H.S. (1957) A simple method for the isolation and purification of total lipids 
from animal tissues. Journal of Biological Chemistry 266, 497-509.

Foster J.R. \& Gabbot P.A. (1971) The assimilation of nutrients from compounded diets by the prawns Palaemon serratus and Pandalus platyceros. Journal of Marine Biological Association of the United Kingdom 51, 943-961.

Gibson O. \& Barker P.L. (1979) The decapod hepatopancreas. Oceanography and Marine Biology Annual Reviews 17, 285-346.

Glass H.J. \& Stark J.R. (1995) Carbohydrate digestion in the European lobster Homarus gammarus (L.). Journal of Crustacean Biology 15, 424-433.

Kohler C. \& Krueger S. (1985) Use of pressed brewer's grain as feed for freshwater prawn (Macrobrachium rosenbergii). Journal of the World Mariculture Society 16, 181-182.

LeeW.J., Sosulski W.F. \& Sokhansanj S. (1991) Yield and composition of soluble and insoluble fractions from corn and wheat stillages. Cereal Chemistry 68, 559-562.

Le Moullac G., Klein B., Sellos D. \& Van Wormhoudt A. (1997) Adaptation of trypsin, chymotrypsin and alpha-amylase to casein level and protein source in Penaeus vannamei (Crustacea Decapoda). Journal of Experimental Marine Biology and Ecology 208, 107-125.

Lim C. (1996) Substitution of cottonseed meal for marine animal protein in diets for Penaeus vannamei. Journal of the World Aquaculture Society 27, 402-409.

Lim C. (1997) Replacement of marine animal protein with peanut meal in diets for juvenile white shrimp, Penaeus vannamei. Journal of Applied Aquaculture 7, 67-78.

Lim C. \& Dominy W. (1991) Utilization of plant proteins by warm water fish. In: Proceedings of the aquaculture feed processing and nutrition workshop (ed. by D.M. Akiyama \& R.K.H. Tan), pp. 163-172. American Soybean Association, Singapore, September 19-25.

Lowry O.H., Rosebrough N.J., Farr A.L. \& Randall R.J. (1951) Protein measurement with the folin-phenol reagent. Journal of Biological Chemistry 193, 265-275.

McGinnis A.J. \& Kasting R. (1964) Colorimetric analysis of chromic oxide to study food utilization and consumption of food by phytophagous insects. Agricultural and Food Chemistry 12, 259-262.

Métailler R. \& Guillaume J. (2001) Raw materials and additives used in fish foods. In: Nutrition and Feeding of Fish and Crustaceans (ed. by J. Guillaume, S. Kaushik, P. Bergot \& R. Métailler), pp. 281-296. Springer-Praxis, Cornwall, UK.

Nelson N. (1944) A photometric adaptation of the Somogyi method for the determination of glucose. The Journal of Biological Chemistry 153, 375-381.

Peñaflorida V.D. (1995) Growth and survival of juvenile tiger shrimp fed diets where fish meal is partially replaced with papaya (Carica papaya L.) or camote (Ipomea batatas Lam.) leaf meal. The Israeli Journal of Aquaculture-Bamidgeh 47, 25-33.

Rick W. \& Stegbauer H.P. (1984) Alfa-amylase. In: Methods of Enzymatic Analysis, Vol. 5 (ed. by H.U. Bergmeyer \&
M. Grab), pp. 885-889. Chemie Verlag, Weinheim, Germany, Academia Press, New York, USA.

Romero I. (1999) Efecto del balance proteína/energía en dietas para camarones juveniles Litopenaeus vannamei. BSc thesis, Universidad de Ciencias Aplicadas y Ambientales, Santafe de Bogota, Colombia, 55pp.

Rosas C., Cuzon G., Gaxiola G., Arena L., Lemaire P., Soyez C. \& VanWormhoudt A. (2000) Influence of dietary carbohydrate on the metabolism of juvenile Litopenaeus stylirostris. Journal of Experimental Marine Biology and Ecology 249, 181-198.

Shiau S.Y. \& Peng C.Y. (1992) Utilization of different carbohydrates at different dietary levels in grass prawn Penaeus monodon, reared in seawater. Aquaculture 101, 241-250.

Sudaryono A., Hoxey M.J., Kailis S.G. \& Evans L.H. (1995) Investigation of alternative protein sources in practical its for juvenile shrimp, Penaeus monodon. Aquaculture 134, 313-323.

Sudaryono A., Tsvetnenko E. \& Evans L.H. (1996) Digestibility studies on fisheries by-product based diets for Pendeus monodon. Aquaculture 143, 331-340.

Tacon A.G.J. \& Akiyama D.M. (1997) Feed ingredients. In: Crustacean Nutrition: Advances in World Aquaculture, Vol. 6 (ed. by L.R. D’Abramo, D.E. Conkklin \& D.M. Akiyama), pp. 411-472. World Aquaculture Society, Baton Rouge, LA, USA.

Tidwell J.H., Webster C.D., Yancey D.H. \& D’Abramo L.R. (1993) Partial and total replacement of fish meal with soybean meal and distillers' by-products in diets for pond culture of the freshwater prawn (Macrobrachium rosenbergii). Aquaculture 118, 119-130.

Treece G. (2000) Shrimp culture. In: Encyclopedia of Aquaculture (ed. by R.R. Stickney), pp. 798-868. John Wiley \& Sons, New York, USA.

Webster C.D.,Tidwell J.H. \& Yancey D.H. (1991) Evaluation of distiller's grains with solubles as a protein source in diets for channel catfish. Aquaculture 96, 179-190.

Webster C.D., Tidwell J.H., Goodgame L.S., Yancey D.H. \& Mackey L. (1992) Use of soybean meal and distillers grains with solubles as partial or total replacement of fish meal in diets for channel catfish, Ictalurus punctatus. Aquaculture 106, 301-309.

Webster C.D., Tidwell J.H., Goodgame L.S. \& Johnsen P.B. (1993) Growth, body composition, and organoleptic evaluation of channel catfish fed diets containing different percentages of distillers' grains with solubles. The Progressive Fish-Culturist 55, 95-100.

Wu Y.V. (1986) Fractionation and characterization of proteinrich material from barley after alcohol distillation. Cereal Chemistry 63, 142-145.

Yamamoto T., Marcouli P.A., Unuma T. \& Akiyama T. (1994) Utilization of malt protein flour in fingerling rainbow trout diets. Fisheries Science 60, 455-460.

Yamamoto T., Unuma T., Akiyama T. \& Kishi S. (1996) Utilization of malt protein flour in the diets for fingerling red sea bream. Fisheries Science 62, 59-63.

Zar J.H. (1999) Biostatiscal Analysis, 4th edn. Prentice-Hall, New Jersey, USA, 663pp. 